\title{
Studies on an Acidic Glycoprotein-Gontaining Fraction Isolated from Guinea-Pig Serum
}

\author{
BY J. L. SIMKIN, E. R. SKINNER AND H. S. SESHADRI \\ Department of Biological Chemistry, University of Aberdeen, Marischal College, Aberdeen
}

(Received 11 June 1963)

Although many of the proteins found in serum contain carbohydrate, there has until recently been relatively little information concerning the nature of the carbohydrate prosthetic groups which such proteins contain, and little is yet known about the metabolism of these glycoproteins. Most of the work on characterization and structure hitherto reported has been carried out on glycoproteins isolated from the serum of larger mammals. Because advantages result from the use of a smaller animal in studies of biosynthesis, an investigation has been begun of the characteristics and structure of certain glycoproteins present in the serum of the guinea pig in order to lay a basis for subsequent work on their biosynthesis.

Two of the most closely examined serum glycoproteins are orosomucoid ( $\alpha_{1}$-acid glycoprotein) and fetuin (see, for example, Winzler, 1960; Spiro, 1960). These are $\alpha$-globulins which are found in the serum of man and the foetal calf respectively. They are characterized by a low isoelectric point and high content of carbohydrate, and are soluble in perchloric acid and trichloroacetic acid. In view of the amount of information now available concerning such acidic glycoproteins, it was decided to study proteins of similar type present in guinea-pig serum. The work so far reported on such guinea-pig glycoproteins (e.g. Weimer \& Winzler, 1955; Boström, Rodén \& Yamashina, 1958) has involved only very limited characterization. Because preliminary work suggested that guinea-pig serum contains many glycoproteins, and in view of the limited quantities of material available from the guinea pig, it was considered that much useful information could be obtained by study of a fraction that contained molecules which were of the type desired and which were basically similar in characteristics. It was found that a fraction of this kind was provided by a very simple procedure involving carboxymethylcellulose, which had been used by Cohen (1957) for the isolation of an $\alpha$ globulin fraction from the serum of the rat. The present paper describes a study of physical and immunological properties and carbohydrate composition of this fraction.

Glycoproteins of the type investigated are usually soluble in perchloric acid (e.g. Winzler, 1960), and advantage has been taken of this in fractionation procedures. The glycoprotein-containing fraction referred to above was found to be almost completely soluble in perchloric acid. It was considered of value to investigate whether the components of this fraction are the only proteins of guinea-pig serum which are soluble in perchloric acid, particularly in light of the fact that the perchloric acid-soluble fraction of serum could prove to be a useful tool in proposed metabolic studies. This is because, as with man (e.g. Winzler, 1960), it is possible to use the magnitude of the amount of the perchloric acid-soluble protein fraction of guinea-pig serum as an index of the occurrence of changes in the concentration of glycoproteins in serum which result from physiological and pathological changes (e.g. Simkin, Skinner \& Seshadri, 1963). Such changes may reflect alterations in the metabolism of the proteins in question.

A preliminary account has been given of some of this work (Simkin et al. 1963).

\section{EXPERIMENTAL} lose.

Abbreviations. DEAE-cellulose, diethylaminoethylcellu-

Materials. These were, wherever possible, of analytical reagent grade. Distilled water passed through a mixed-bed ion-exchange resin was used for ion-exchange chromatography.

Physical measurements. Extinctions at $280 \mathrm{~m} \mu$ were measured with a Hilger Uvispek spectrophotometer. Measurements of $\mathrm{pH}$ were made with an Electronic Industries Ltd. model $23 \mathrm{~A}$ pH-meter.

\section{Preparation of serum}

Guinea pigs, 400-750 g. body wt., of either sex, purchased from A. J. Tuck and Son, Rayleigh, Essex, were starved overnight before use. Blood shed on cutting the jugular veins of three-five anaesthetized animals was pooled, allowed to stand for $20-40 \mathrm{~min}$. to clot and then centrifuged. The serum obtained was used without delay with the exception of that employed for comparison with test material in some experiments involving immunological or electrophoretic methods, which was stored at $-20^{\circ}$ before use.

\section{Preparation of fractions}

Preparation of fraction I. Carboxymethylcellulose was prepared as described by Peterson \& Sober (1956) from Whatman Cellulose Powder for Chromatography, which had first been passed through a 200-mesh sieve. Before 
use, it was washed twice with $0.25 \mathrm{~N}-\mathrm{NaOH}-0.25 \mathrm{M}-\mathrm{NaCl}$ and then with water. An acetate buffer, $\mathrm{pH} 5 \cdot 0$, containing $35 \mathrm{~mm}$-sodium acetate and $15 \mathrm{~mm}$-acetic acid was used throughout the following procedure. The exchanger was washed three times with this buffer and columns were prepared. All subsequent procedures were carried out at $2^{\circ}$. Guinea-pig serum was dialysed against two changes of $30 \mathrm{vol}$. of buffer over a total period of about $22 \mathrm{hr}$. The non-diffusible material was centrifuged and the supernatant taken for chromatography. Columns containing a bed of exchanger either $8 \mathrm{~cm} . \times 2 \mathrm{~cm}$. or $8 \mathrm{~cm} . \times 3 \cdot 3 \mathrm{~cm}$. were customarily used: $5 \mathrm{ml}$. of dialysed serum was applied to the smaller columns and $12 \mathrm{ml}$. to the larger. After the application of serum and several washes of buffer, buffer was passed through at 0.5 or $1.0 \mathrm{ml} . / \mathrm{min}$. according to the size of column used; a total of 30-36 fractions, each of 2 or $4 \mathrm{ml}$. respectively, were collected. The protein content of the fractions was determined by measurement of extinction at $280 \mathrm{~m} \mu$. Appropriate fractions were pooled and dialysed against three changes each of $40 \mathrm{vol}$. of water over a total period of $20 \mathrm{hr}$. The non-diffusible material was then centrifuged to remove any small amount of insoluble material. The supernatant was freeze-dried and stored over $\mathrm{CaCl}_{2}$ at $2^{\circ}$. In a few experiments, the pooled fractions from chromatography were dialysed against about 50 vol. of water for $5-20 \mathrm{hr}$. and then reduced to small volume by ultrafiltration through dialysis tubing immersed in water in an evacuated chamber, the procedure used (hereafter referred to as ultrafiltration) being in principle that of Sober, Gutter, Wycoff \& Peterson (1956). The concentrate was centrifuged and, if necessary, stored at $-20^{\circ}$. Such concentrates did not differ significantly from solutions of freeze-dried fraction $I$, as judged by double-diffusion analysis with anti-fraction $I$ and starch-gel electrophoresis with the $\mathrm{pH} 9$ buffer system (see below).

Preparation of perchloric acid-soluble protein fraction. In all experiments, the general procedure and relative volumes of serum, saline and perchloric acid were as described below. A typical preparation was made as follows: $15 \mathrm{ml}$. of serum was diluted with $135 \mathrm{ml}$. of $0.9 \% \mathrm{NaCl}$, and $75 \mathrm{ml}$. of 1.8 M-perchloric acid was added slowly (during 6-8 min.) with stirring at room temperature. The mixture was then allowed to stand for $10 \mathrm{~min}$. with occasional stirring and filtered through Whatman no. 54 paper. The filtrate was allowed to pass directly into a funnel containing a Whatman no. 50 paper. The second filtrate was collected in a receiver standing in ice. Filtration required 30-50 min. Ice-cold $\mathrm{NaOH}$ (2N or less) was added to the iced filtrate until the $\mathrm{pH}$ reached about $6 \cdot 5$. The mixture was concentrated to about $50 \mathrm{ml}$. by ultrafiltration with concurrent dialysis against water at $2^{\circ}$. The concentrate was centrifuged and the supernatant was freeze-dried. The material so obtained is referred to as the perchloric acid-soluble protein fraction; it was stored over $\mathrm{CaCl}_{2}$ at $2^{\circ}$.

Chromatography of the perchloric acid-soluble protein fraction on carboxymethylcellulose. A column of carboxy. methylcellulose, $8 \mathrm{~cm} . \times 2 \mathrm{~cm}$., equilibrated with $50 \mathrm{~mm}$ acetate buffer, $\mathrm{pH} 5 \cdot 0$, was prepared as described above for isolation of fraction I; the same acetate buffer was used throughout the following procedure, all of which was carried out at $2^{\circ}$. A solution of about $30 \mathrm{mg}$. of perchloric acid-soluble protein fraction in acetate buffer $(3 \mathrm{ml}$.) was applied to the column. The column was eluted with about $40 \mathrm{ml}$. of buffer. In one experiment, elution was further continued with buffer containing an increasing concentration of $\mathrm{NaCl}$. The gradient was produced by means of two cylindrical vessels which differed in diameter in a ratio of about 2:1. The larger vessel, which acted as mixing chamber, contained $127 \mathrm{ml}$. of buffer and the smaller one $38 \mathrm{ml}$. of buffer $-1 \cdot 36 \mathrm{M}-\mathrm{NaCl}$. The flow rate through the column was about $20 \mathrm{ml} . / \mathrm{hr}$. Extinction of the fractions was measured at $280 \mathrm{~m} \mu$ and chloride was estimated by a Volhard procedure. Appropriate fractions were pooled and concentrated to small volume by ultrafiltration with concurrent dialysis against water. Any insoluble material was removed by centrifuging.

Treatment of fraction I with perchloric acid. To study the effect of contact with perchloric acid, fraction I was subjected to conditions, including time of exposure, which were similar to those used for preparation of the perchloric acid-soluble protein fraction (see above). A solution of $4.5 \mathrm{mg}$. of fraction $\mathrm{I}$ in $1 \mathrm{ml}$. of water was diluted with $9 \mathrm{ml}$. of $0.9 \% \mathrm{NaCl}$ and $5 \mathrm{ml}$. of $1.8 \mathrm{M}$-perchloric acid added. The mixture was then treated in an analogous manner to that described for the preparation of the perchloric acidsoluble protein fraction. A control was set up in which the perchloric acid and $\mathrm{NaOH}$ added were replaced by a similar volume of $0.9 \% \mathrm{NaCl}$.

\section{Immunological methods}

Preparation of rabbit antisera. Antisera to fraction I, perchloric acid-soluble protein fraction and guinea-pig serum were prepared by administration of two intramuscular injections 1 week apart of an emulsion of antigen with Freund's complete adjuvant (Difco Laboratories Inc.). Three weeks later, a series of intravenous injections was given of a coprecipitate of antigen with $\mathrm{Al}(\mathrm{OH})_{3}$. For preparation of antiserum to guinea-pig serum albumin, the antigen was prepared by a method based on that of Campbell \& Stone (1957) and administered as a series of intravenous injections of a coprecipitate with $\mathrm{Al}(\mathrm{OH})_{3}$.

Double-diffusion analysis. This was based on the technique of Ouchterlony (1953). The medium used contained $\mathbf{1 . 2 5} \%(\mathrm{w} / \mathrm{v})$ of Nobel agar (Difco Laboratories Inc.), $0.9 \%$ of $\mathrm{NaCl}$ and $0.01 \%$ of thiomersal. Development took place at room temperature and a series of photographs was taken with the aid of an illumination system similar to that of Hunter (1959).

\section{Electrophoretic methods}

Cellulose acetate. Electrophoresis was carried out with cellulose acetate strips $(5 \mathrm{~cm} . \times 20 \mathrm{~cm}$.; Oxo Ltd.) as described by Kohn (1960). The following buffers were used: (a) veronal, pH 8.6, containing $8.3 \mathrm{~mm}$-diethylbarbituric acid and $41.6 \mathrm{~mm}$-sodium diethylbarbiturate; $(b)$ citratephosphate, ranging from $\mathrm{pH} 3.4$ to 4.5 and all of which had a total concentration of $30 \mathrm{~mm}$; e.g. the buffer of $\mathrm{pH} 3.5$ (the approximate isoelectric point of the major part of fraction I, see the Results section) contained 16 mM-citric acid and $13.9 \mathrm{~mm}-\mathrm{Na}_{2} \mathrm{HPO}_{4}$. A potential of $140 \mathrm{v}$ was applied for $5.5 \mathrm{hr}$. with $(a)$ or $7 \mathrm{hr}$. with $(b)$. Strips were stained for protein with Naphthalene Black 10B (Kohn, 1958) or for carbohydrate by the periodic acid-Schiff technique (Kohn, 1960). When correction for electroosmotic flow was required, dextran $(10 \%, \mathrm{w} / \mathrm{v}$, solution) and the protein sample were subjected to electrophoresis side by side on the same strip (Kunkel \& Tiselius, 1951). 
Starchgel. The horizontal procedure of Smithies (1955) was followed. Starch, Hydrolysed for Gel Electrophoresis, was purchased from the Connaught Medical Research Laboratories, Toronto. The troughs used measured either $2 \mathrm{~cm}$. or $6 \mathrm{~cm} . \times 17.5 \mathrm{~cm} . \times 0.6 \mathrm{~cm}$., and samples were inserted on Whatman no. 3 paper. The following buffers were used: the electrode and bridge compartments were filled with a buffer solution ten times the concentration of that given, except in $(a)$, where the second-named buffer was used for this purpose: (a) $\mathrm{pH} 9 \cdot 0$ system: (1) $76 \mathrm{~mm}$-tris and 5 mM-citric acid, pH 9.0; (2) 300 mM-boric acid and $50 \mathrm{~mm}-\mathrm{NaOH}, \mathrm{pH} 8.2$ (cf. Poulik, 1957); (b) phosphate, pH 6.0: $26.3 \mathrm{~mm}-\mathrm{NaH}_{2} \mathrm{PO}_{4}$ and $3.9 \mathrm{~mm}-\mathrm{Na}_{2} \mathrm{HPO}_{4} ; \quad(c)$ acetate, $\mathrm{pH} \mathrm{4.4:} 11.1 \mathrm{~mm}$-sodium acetate and $18.9 \mathrm{~mm}$ acetic acid; $(d)$ citrate, $\mathrm{pH} 3 \cdot 4: 6.9 \mathrm{~mm}$-sodium citrate and $21.6 \mathrm{~mm}$-citric acid. With (a), 170v was applied for $5.5 \mathrm{hr}$. at room temperature; with $(b),(c)$ and $(d), 50,70$ and $80 \mathrm{v}$ respectively were applied for $18 \mathrm{hr}$. at $2^{\circ}$. Gels were stained for protein with Naphthalene Black 10 B (Smithies, 1955) or for lipid with Lipid Crimson (Bodman, 1960). Protein fractions were eluted from starch gel by a procedure based on that of Moretti, Boussier \& Jayle (1958). The bands removed from the gels contained in three $2 \mathrm{~cm} . \times 17.5 \mathrm{~cm} . \times 0.6 \mathrm{~cm}$. troughs were pooled together. The contents of the dialysis sac were concentrated by ultrafiltration with concurrent dialysis against water, centrifuged and the supernatant was taken for examination.

Two-dimensional electrophoresis (cf. Poulik \& Smithies, 1958). Electrophoresis in the first dimension was carried out with cellulose acetate and veronal buffer, pH 8.6, as above; samples were applied to a $3 \mathrm{~cm}$.-wide starting line. After electrophoresis, a strip $11 \mathrm{~cm} . \times 0.55 \mathrm{~cm}$. was cut out of the centre of the protein-containing area and inserted into a trough of starch gel measuring $12 \mathrm{~cm} . \times 17.5 \mathrm{~cm} . \times$ $0.6 \mathrm{~cm}$. Electrophoresis was carried out with the $\mathrm{pH} 9 \cdot 0$ system as above.

Immunoelectrophoresis. Electrophoresis was carried out as above with either cellulose acetate and $\mathrm{pH} 8.6$ buffer or starch gel and the $\mathrm{pH} \mathrm{9.0}$ system. Subsequent reaction with antiserum was carried out by procedures based on those of Kohn (1960) and Bodman (1960) respectively.

\section{Ultracentrifuge analysis}

Examinations were made with a Spinco model E ultracentrifuge at $16-24^{\circ}$. The buffer used was of $\mathrm{pH} 8.4$ and contained $50 \mathrm{~mm}$-sodium diethylbarbiturate, $11 \mathrm{~mm}-\mathrm{HCl}$ and $157 \mathrm{~mm}-\mathrm{NaCl}$. Sedimentation velocity was determined at $59780 \mathrm{rev} . / \mathrm{min}$. with analytical rotor $\mathrm{A}$. The investigation with a synthetic boundary cell was carried out at $13410 \mathrm{rev} / \mathrm{min}$. For examination by the method of Archibald (see Schachman, 1959), 0.1 ml. of MS 500 silicone oil was used to provide the bottom meniscus.

\section{Chemical analyses}

The analyses described below refer specifically to those applied to fraction I; some were also applied to the perchloric acid-soluble protein fraction, the methods used being summarized in the appropriate section of Results.

Materials. Pentoses and hexoses were purchased from either British Drug Houses Ltd. or from Thomas Kerfoot and Co. Ltd. Glucosamine hydrochloride and $N$-acetylglucosamine were purchased from British Drug Houses Ltd., and galaotosamine hydrochloride from Sigma Chemical
Co.; for use in quantitative experiments, these substances were recrystallized before use. $N$-Acetylgalactosamine was prepared by an adaptation of the method described below for acetylation of hexosamines. Glucuronic acid was from the California Corp. for Biochemical Research. $N$-Acetylneuraminic acid was either synthetic material obtained from L. Light and Co. Ltd. or Miss P. M. Carroll (Royal National Orthopaedic Hospital, Stanmore, Middx.) or material isolated from sheep maxillary mucin. $N$-Glycollylneuraminic acid was isolated from pig mucin and $N$-acetyl4- $O$-acetylneuraminic acid from horse mucin. The samples isolated from mucins (Blix, Lindberg, Odin \& Werner, 1956) were obtained from Professor G. Blix (Medical Chemical Institute, Uppsala, Sweden). Acetylcholine chloride was obtained from British Drug Houses Ltd. Ethyl acetate was of A.R. grade and was redistilled before use. Bovine serum albumin was a crystalline product purchased from Armour Pharmaceutical Co. Ltd. Substances used to standardize quantitative procedures were allowed to stand over $\mathrm{CaCl}_{2}$ before use.

Ion-exchange resins. Dowex 50 (X8) and Dowex 2 (X8), both 200-400 mesh, were used throughout. Both were periodically washed with organic solvents as described by Montreuil \& Scheppler (1959). Dowex 50 was converted into the $\mathrm{H}^{+}$form. Dowex 2 was always first washed with $6 \mathrm{~N}-\mathrm{NaOH}$ and then water. It was then converted into the required form. Except where indicated, the columns used contained a bed of resin $5 \mathrm{~cm} . \times 0 \cdot 6 \mathrm{~cm}$.

Paper chromatography. Downward development at room temperature was employed throughout. Unless otherwise stated, Whatman no. 3 paper was used with solvent $A$ and Whatman no. 1 paper with other solvents. The organic solvents used were redistilled reagent-grade samples. Solvent A: butan-1-ol-ethanol-water (10:1:2, by vol.); solvent B: butan-1-ol-pyridine-water (6:4:3, by vol.); solvent C: butan-1-ol-acetic acid-water (4:1:5, by vol.); solvent D: pyridine-isopentan-1-ol-0.1 N-HCl $(2: 2: 1$, by vol.) (Bourrillon \& Michon, 1959); solvent E: butan-1-olpropan-1-ol-0.1 N-HCl (1:2:1, by vol.) (Svennerholm \& Svennerholm, 1958). Detection reagent (1) refers to aniline phthalate (Partridge, 1949), (2) is aniline phosphate (Frahn \& Mills, 1959), (3) is benzidine-trichloroacetic acid-HCl (procedure d; Chan \& Cain, 1961), and (4) is $\mathrm{AgNO}_{3}$ (Trevelyan, Procter \& Harrison, 1950).

Dry weight. Samples were heated at $105^{\circ}$ until of constant weight.

Protein. This was determined by the method of Lowry, Rosebrough, Farr \& Randall (1951) but with the modified reagents and volumes described by Miller (1959). Bovine serum albumin was used as standard; the solutions used were of known total $\mathrm{N}$ content.

Total hexose. This was determined by the orcinol method described by Winzler (1955). An equimolar mixture of galactose and mannose was used as standard.

Serum protein-bound hexose. This was measured as described by Winzler (1955). An equimolar mixture of galactose and mannose was used as standard.

Fucose. This was estimated by the cysteine- $\mathrm{H}_{2} \mathrm{SO}_{4}$ method of Dische \& Shettles (1948) applied directly to fraction $I$. The nature of the products formed in the reaction was examined by the procedure of Dische \& Shettles (1951).

Hydrolysis with Dowex 50-hydrochloric acid and fractionation of hydrolysates. For qualitative and quantitative 
analysis of neutral sugar, hexosamine and uronic acid, fraction I was hydrolysed with Dowex 50 and $\mathrm{HCl}$ by a modification of the method of Anastassiadis \& Common (1958) and Haab \& Anastassiadis (1961). Hydrolysates were then fractionated by a modification of the method of Montreuil \& Scheppler (1959).

Dowex $50\left(\mathrm{H}^{+}\right.$form) was washed with a volume of $0.46 \mathrm{~N}-\mathrm{HCl}$ equal to five times the volume of wet resin and then suspended in a volume of $0.46 \mathrm{~N}-\mathrm{HCl}$ equal to that of the wet resin. A solution of about $1 \cdot 5-2.5 \mathrm{mg}$. of fraction I in $0.25 \mathrm{ml}$. of water and $0.6 \mathrm{ml}$. of resin suspension were placed in a Pyrex tube, $9 \mathrm{~cm} . \times 0.8 \mathrm{~cm}$, and the tube was sealed. The hydrolysis mixture thus contains about $150 \mathrm{mg}$. dry wt. of Dowex 50 and about $0.6 \mathrm{ml}$. of $0.25 \mathrm{~N}-\mathrm{HCl}$. The tube was heated in an oven for $30-36 \mathrm{hr}$. at $100^{\circ}$. The tube was maintained at an angle of $45^{\circ}$ and turned through $180^{\circ}$ about 20 times during hydrolysis to mix the contents.

For fractionation of hydrolysates, an arrangement was made such that the filtrate from a small funnel with a $1 \mathrm{~cm}$. diameter no. 1 sinter could pass through a column of Dowex $50\left(\mathrm{H}^{+}\right.$form) and the effluent from the latter could pass directly through a column of Dowex 2 (formate form). The hydrolysis mixture and five $0.5 \mathrm{ml}$. washings of the ampoule were successively transferred to the funnel. The filtrates were pooled and passed through both columns. The resin in the funnel was then washed repeatedly with water (total $7.5 \mathrm{ml}$.), each wash being allowed to flow through both columns. Finally, two $2.5 \mathrm{ml}$. portions of water were passed successively through the columns. The combined effluents from the column of Dowex 2 were evaporated to dryness in vacuo at $35^{\circ}$; the residue is referred to as the neutral sugar fraction. The resin used for hydrolysis was then eluted successively with $0.25 \mathrm{ml}$. of $2 \mathrm{~N}-\mathrm{HCl}$, two $0.25 \mathrm{ml}$. portions of water and $0.25 \mathrm{ml}$. of $2 \mathrm{~N}-\mathrm{HCl}$. The washes were pooled and allowed to pass through the column of Dowex 50 and the effluent was rejected. The column of Dowex 50 was then eluted with $3 \mathrm{ml}$. of $2 \mathrm{~N}-\mathrm{HCl}$ (Boas, 1953). The eluate was collected and evaporated to dryness in vacuo at $35^{\circ}$; the residue is referred to as the hexosamine fraction. In some experiments, after preparation of the neutral sugar fraction, the column of Dowex 2 was eluted with $8 \mathrm{ml}$. of $1 \cdot 2 \mathrm{~N}$-formic acid (Montreuil, 1957). Formic acid was removed from the eluate by evaporation in vacuo at $35^{\circ}$ as follows: the eluate was concentrated to onethird of its original volume. A volume of water was added equal to that of the concentrate and the mixture reduced to one-third volume. A volume of water equal to that of this concentrate was added and the solution evaporated to dryness. The residue obtained is referred to as the uronic acid fraction.

The fractions obtained by the above procedure were analysed as described below. In all quantitative and in some qualitative experiments, two kinds of control were included, these being subjected to the conditions of hydrolysis, fractionation and analysis. The assay solution was replaced by either $0.25 \mathrm{ml}$. of water or by $0.25 \mathrm{ml}$. of a solution which usually contained $1 \cdot 5-2 \mathrm{mg}$. of bovine serum albumin, $75 \mu \mathrm{g}$. each of galactose and mannose, and $100-120 \mu \mathrm{g}$. of glucosamine (this mixture simulated the composition of fraction I). When uronic acid was determined, $2 \cdot 5 \mu \mathrm{g}$. of glucuronic acid was added to each control mixture.

Neutral siggar. The neutral sugar fraction was examined qualitatively. (a) By paper chromatography with: solvent $A$ and detection reagent (1); solvent $D$ and reagent (3); pyridine-ethyl acetate-water (1:2:2, by vol.) with reagents (2) and (4). (b) By paper electrophoresis with the sodium tetraborate, $\mathrm{pH} \mathbf{9} \cdot \mathbf{2}$, or sodium arsenite, $\mathrm{pH} 9 \cdot 6$, buffers described by Frahn \& Mills (1959); detection reagents (4) and (2) respectively were used. Whatman no. 4 paper was employed. The apparatus was of the closed-strip type and about $35 \mathrm{v} / \mathrm{cm}$. was applied.

The only sugars detected in the neutral sugar fraction were galactose and mannose and these were determined quantitatively as follows. The neutral sugar fraction was dissolved in $100 \mu \mathrm{l}$. of water and $60-80 \mu \mathrm{l}$. of the solution was applied to Whatman no. 3 paper. After chromatography with solvent $A$ for $48 \mathrm{hr}$., the paper was dried at room temperature and the positions of galactose and mannose were determined by spraying guide strips with reagent (1). The areas containing galactose and mannose were cut out together with areas of blank paper taken from a level similar to that of galactose or mannose. Sugar was eluted by immersing each piece of paper in $10 \mathrm{ml}$. of water and one drop of S-free toluene for $12-16 \mathrm{hr}$. at $2^{\circ}$. After centrifuging, samples of the supernatant were analysed for reducing sugar (Park \& Johnson, 1949). Either galactose or mannose was used as standard.

Hexosamine. The hexosamine fraction was examined qualitatively as follows. (a) Ion-exchange chromatography based upon the procedure of Gardell (1953) of the fraction alone and a mixture of it with glucosamine. The hexosamine content of the fractions was determined as described below. (b) Paper chromatography. The material present in the only peak detected under $(a)$ was examined by paper chromatography with pyridine-ethyl acetatewater-acetic acid (5:5:3:1, by vol.) (Fischer \& Nebel, 1955), combined with the Elson-Morgan detection reagents of Partridge (1948) or $0.2 \%$ ninhydrin in butan-1-ol. (c) Oxidation to pentose (Stoffyn \& Jeanloz, 1954). The reaction mixture obtained was evaporated to dryness in vacuo and the residue examined by paper chromatography with butan-1-ol-ethanol-water (4:1:1, by vol.) and detection reagent (1). (d) Conversion into acetyl derivative as described by Roseman \& Daffner (1956). After heating to destroy excess of anhydride, the mixture was desalted by successive passage through columns of Dowex $50\left(\mathrm{H}^{+}\right.$form) and Dowex 2 (formate form). Two volumes each of $5 \mathrm{ml}$. of water were then passed successively through the columns and the combined effluents were evaporated to dryness in vacuo at $35^{\circ}$. The residue was examined by chromatography with solvent $B$ on paper treated with metaborate buffer, pH 8.2 (Cardini \& Leloir, 1957); the Morgan-Elson detection method of these authors was used.

Quantitative determination of hexosamine was by the method of Kraan \& Muir (1957). Glucosamine hydrochloride was used as standard.

Uronic acid. For each analysis, the uronic acid fractions obtained from three hydrolysates or control hydrolysates were pooled. Qualitative examination was made by chromatography on Whatman no. 1 paper with solvent $A$ and detection reagent (3). This system does not distinguish between glucuronic acid and galacturonic acid. Uronic acid was determined quantitatively as by Bitter \& Ewins (1961). Glucuronic acid was used as standard.

Sialic acid. Fraction I was treated with either (1) dilute acid or (2) neuraminidase. 
(1) A mixture of $2.5-3.5 \mathrm{mg}$. of fraction I with $2.0 \mathrm{ml}$. of $0.05 \mathrm{~N}-\mathrm{H}_{2} \mathrm{SO}_{4}$ was heated in a glass-stoppered tube at $90^{\circ}$ (Svennerholm, 1958) for 35 or $60 \mathrm{~min}$. The hydrolysate was applied without delay to a column of Dowex 2 (formate form) (Svennerholm, 1956); chromatography was carried out at $2^{\circ}$. The column was washed successively with $2 \times 0.5 \mathrm{ml}$. and $2 \times 2.5 \mathrm{ml}$. of water; the effluents were discarded. The column was then eluted with $15 \mathrm{ml}$. of $0.3 \mathrm{~N}$ formic acid, which was then removed as described above for preparation of the uronic acid fraction. The residue was examined by paper chromatography; chromatograms were sprayed with the periodate-thiobarbituric acid system of Warren (1960). To investigate whether any residues other than sialic acid were removed by heating fraction $I$ with $0.05 \mathrm{~N}-\mathrm{H}_{2} \mathrm{SO}_{4}$ at $90^{\circ}$ for $60 \mathrm{~min}$., two experiments were carried out. (i) An hydrolysate of about 3.5 mg. of fraction I $\left(3.5 \mathrm{ml}\right.$. of $\left.\mathrm{H}_{2} \mathrm{SO}_{4}\right)$ was dialysed against $3 \times 15 \mathrm{ml}$. of water at $2^{\circ}$ over a total period of $24 \mathrm{hr}$. The diffusible material was pooled and concentrated in vacuo to about $1 \mathrm{ml}$. Samples were removed for analysis by the orcinol method (see above) and the remainder was mixed with an equal volume of $2 \mathrm{~N}-\mathrm{H}_{2} \mathrm{SO}_{4}$ and heated in a sealed tube at $100^{\circ}$ for $12 \mathrm{hr}$. The hydrolysate was neutralized with $\mathrm{N}$ $\mathrm{NaOH}$ and analysed by the ninhydrin method of Yemm \& Cocking (1955). (ii) An hydrolysate of $20 \mathrm{mg}$. of fraction I $\left(5 \mathrm{ml}\right.$. of $\left.0.05 \mathrm{~N}-\mathrm{H}_{2} \mathrm{SO}_{4}\right)$ was applied to a $26 \mathrm{~cm} . \times 2 \mathrm{~cm}$. column of Sephadex G-25 (Pharmacia, Uppsala) (see e.g. Porath, 1960), which had been washed with $0.9 \% \mathrm{NaCl}$ and then water. The column was eluted with water at a flow rate of $0.25 \mathrm{ml} . / \mathrm{min}$. Fractions $(1.5 \mathrm{ml}$.) were collected and their extinction at $280 \mathrm{~m} \mu$ was determined. Fractions corresponding to non-retarded material were pooled and dialysed against water for $5 \mathrm{hr}$. The non-diffusible material was then freeze-dried and analysed as for fraction $I$. Fractionation and dialysis were carried out at $2^{\circ}$.

(2) A crude preparation of neuraminidase was obtained by fractionation of culture filtrate from Vibrio cholerae with methanol at $-5^{\circ}$ (cf. Ada, French \& Lind, 1961). An aqueous solution of freeze-dried cholera filtrate (N. V. Philips-Duphar, Amsterdam) was adjusted to $\mathrm{pH} 5$ with $0.1 \mathrm{~N}-\mathrm{HCl}$, and $1.5 \mathrm{vol}$. of methanol was added. The mixture was centrifuged and the precipitate obtained dissolved in water, $1 \mathrm{ml}$. being added for each $10 \mathrm{ml}$. ampoule originally taken. The solution was dialysed at $2^{\circ}$ against water. The non-diffusible material was centrifuged and the supernatant taken as the enzyme preparation. Fraction I was incubated with neuraminidase at $37^{\circ}$, reaction mixtures being buffered with a final concentration of either $39 \mathrm{~mm}$-calcium acetate-11 mM-acetic acid, $\mathrm{pH} \mathbf{5 \cdot 5}$. or 40 mm-tris-20 mm-maleic acid-1 $\mathrm{mm}-\mathrm{CaCl}_{2}, \mathrm{pH} \mathrm{5 \cdot 6}$. The amounts of fraction $I$ and neuraminidase used in representative experiments are given in the Results section. To investigate the nature of the material released by neuraminidase, $2.0 \mathrm{ml}$. of incubation mixture was passed through a column of Dowex $50\left(\mathrm{H}^{+}\right.$form) of the usual size and the effluent passed through a $20 \mathrm{~cm} . \times 0 \cdot 6 \mathrm{~cm}$. column of Dowex 2 (formate form). The Dowex 50 was washed with $2 \times 0.5 \mathrm{ml}$. of water and the washes were passed through the Dowex 2. The column of Dowex 2 was then eluted successively with $70 \mathrm{ml}$. of $0.1 \mathrm{~N}$-formic acid and $25 \mathrm{ml}$. of $0.3 \mathrm{~N}$-formic acid at a rate of about $10 \mathrm{ml}$. $\mathrm{hr}$. The entire chromatographic procedure was carried out at $2^{\circ}$. Fractions $(1.5 \mathrm{ml}$.) were collected and samples $(0.5 \mathrm{ml}$.) were analysed by method $(a)$ below. Appropriate fractions were pooled and formic acid was removed by evaporation as described above. The residue was examined by paper chromatography. The extent of release of sialic acid brought about by neuraminidase was usually studied by analysis of the free sialic acid content of incubation mixtures by method $(a)$ below. In several experiments, however, the incubation mixture containing neuraminidase was placed in a dialysis sac, which was attached to a stirrer immersed in 50 vol. of buffer; for subsequent details of incubation, see the Results section. To determine the extent of release of sialic acid in such experiments, the incubated mixture was dialysed at $2^{\circ}$ against water for $16 \mathrm{hr}$. and samples of the non-diffusible material were taken for hydrolysis and analysis by method $(a)$ as described below. To study the effect of treatment of fraction I with dilute alkali before incubation with neuraminidase, an aqueous solution of fraction $I(9 \mathrm{mg} . / \mathrm{ml}$.) was adjusted to $\mathrm{pH} 9.5$ with $\mathrm{NaOH}$ and allowed to stand at $2^{\circ}$ for $16 \mathrm{hr}$. The $\mathrm{pH}$ was then adjusted to 5.6 with $\mathrm{HCl}$ and the solution treated with neuraminidase as described in the Results section.

For quantitative analysis of sialic acid, hydrolysis was with $0.05 \mathrm{~N}-\mathrm{H}_{2} \mathrm{SO}_{4}(2.0 \mathrm{ml}$. $)$ at $90^{\circ}$ for $60 \mathrm{~min}$.: either about $1.5 \mathrm{mg}$. of fraction I was hydrolysed and samples of $0.3 \mathrm{ml}$. of hydrolysate were analysed by method $(a)$, or $2 \cdot 5-3.5 \mathrm{mg}$. was hydrolysed and the entire hydrolysate analysed by method (b). $N$-Acetylneuraminic acid was used as standard. Controls in which the assay solution was replaced by either water or a solution containing $100 \mu \mathrm{g}$. of $N$-acetylneuraminic acid and 1.5 -2.0 mg. of bovine serum albumin were also subjected to hydrolysis and analysis. Method (a) was the periodate-thiobarbituric acid procedure described by Aminoff (1961). Method (b) was a modification of the procedure of Svennerholm (1958). The hydrolysate was fractionated without delay by chromatography with Dowex 2 (acetate form) at $2^{\circ}$. Eluates were analysed by the resorcinol method of Svennerholm (1958). The coloured product formed was, however, extracted by means of the solvent mixture described by Miettinen \& Takki-Luukkainen (1959).

Acetyl. Total acetyl was determined by the method of Ludoweig \& Dorfman (1960) and $O$-acetyl as described by Hestrin (1949). Efforts were made to remove from samples to be used for analysis of total acetyl any acetate which might remain after the customary method used for isolation of fraction I. Two procedures were used: $(a)$ dialysis with vigorous stirring of $0.5 \mathrm{ml}$. of solution of fraction I against $3 \times 2$ l. of water at $2^{\circ}$ over a total period of $6 \mathrm{hr}$.; (b) a solution containing $10 \mathrm{mg}$. of fraction I was applied to a $10 \mathrm{~cm} . \times 1 \mathrm{~cm}$. column of diethylaminoethylcellulose (prepared as described by Peterson \& Sober, 1956) that had been equilibrated with $9.5 \mathrm{~mm}-\mathrm{Na}_{2} \mathrm{HPO}_{4}-0.6 \mathrm{~mm}$ $\mathrm{NaH}_{2} \mathrm{PO}_{4}, \mathrm{pH} \mathrm{8.0.} \mathrm{The} \mathrm{column} \mathrm{was} \mathrm{eluted} \mathrm{with} 45 \mathrm{ml}$. of the same buffer. Fraction $I$ is adsorbed by the exchanger under these conditions (unpublished work) and the effluent was rejected. The column was then eluted with $25 \mathrm{ml}$. of $28 \mathrm{~mm}-\mathrm{Na}_{2} \mathrm{HPO}_{4}-197 \mathrm{~mm}-\mathrm{NaH}_{2} \mathrm{PO}_{4}, \mathrm{pH} \mathrm{6.0.}$ Fractions of effluent containing protein were pooled and concentrated by ultrafiltration with concurrent dialysis against water. The entire procedure was carried out at $2^{\circ}$. Samples of about $4.5 \mathrm{mg}$. of fraction I were taken for each analysis; for qualitative analysis of total acetyl, only material treated by method (a) above was investigated. For quantitative analysis of total acetyl, ethyl acetate was 
used as standard and $N$-acetylglucosamine was analysed concurrently with fraction I as an additional control. For determination of $O$-acetyl, acetylcholine was used as standard. For qualitative investigation of hydroxamate formed after reaction with alkaline hydroxylamine as in the quantitative procedures, mixtures were adjusted to pH 7.5 with $\mathrm{N}-\mathrm{HCl}$ and then evaporated to dryness in vacuo over $\mathrm{H}_{2} \mathrm{SO}_{4}$. Each residue was extracted with several volumes $(0.25-0.5 \mathrm{ml}$.) of ether-methanol $(10: 1, \mathrm{v} / \mathrm{v})$. The extracts were pooled, centrifuged and the supernatant was evaporated to dryness in vacuo. The residue was examined by paper chromatography with solvent $\mathrm{C}$. The $\mathrm{FeCl}_{3}$ reagent of Thompson (1951) was used for detection. Marker hydroxamates were prepared either by a method similar to that of Thompson (1951) or from the appropriate acids by application of the method used for investigation of total acetyl.

\section{RESULTS}

\section{Preparation of fraction I and re-chromatography}

When guinea-pig serum is applied to a column of carboxymethylcellulose equilibrated with $50 \mathrm{~mm}$ acetate buffer, $\mathrm{pH} 5 \cdot 0$, most of the proteins present are adsorbed. The material which passes through the column elutes in the form of two peaks, material included in the first of which is referred to as fraction I (Fig. 1). The substances present in the second peak, fraction II, have not been examined in detail : they consist mainly of $\alpha$-globulins of slower electrophoretic mobility which stain for carbohydrate (unpublished work).

The yield of fraction $I$ is about $2.5 \mathrm{mg} . / \mathrm{ml}$. of serum. The concentration of protein-bound hexose in guinea-pig serum was found to be $1 \cdot 16 \mathrm{mg} . / \mathrm{ml}$. (average of nine values). The amount of hexose isolated as fraction I corresponds to about $15 \%$ of

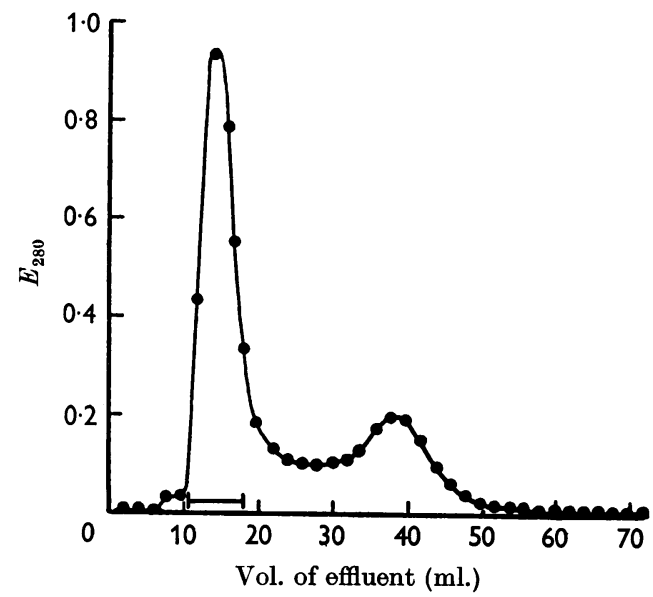

Fig. 1. Chromatography of guinea-pig serum on carboxymethylcellulose $(8 \mathrm{~cm} . \times 2 \mathrm{~cm}$. column), equilibrated and eluted with 50 mm-acetate buffer, pH 5.0. The fractions indicated were pooled and taken as fraction $[$. the protein-bound hexose of guinea-pig serum (cf. Table 1).

Re-chromatography of fraction I $(3 \mathrm{mg}$. in $1.5 \mathrm{ml}$. of buffer) on a $11 \mathrm{~cm} . \times 1 \mathrm{~cm}$. column of carboxymethylcellulose showed that almost all of the material applied was eluted in the form of a single sharp peak. The volume of buffer required for elution was similar to that required for elution of fraction $I$. When the re-chromatographed fraction I was examined by starch-gel electrophoresis with the pH 9 buffer system, all of the bands of protein normally detected by this procedure (see below) were found and their relative proportions were essentially similar to those of the bands obtained with untreated fraction $I$; there was an additional faint band of relatively low mobility.

\section{Immunological and physical properties of fraction I}

Double-diffusion immunological analysis. After reaction of fraction I with anti-(guinea-pig serum), four precipitin lines were seen, one of which gave a reaction of identity with a line formed by guineapig serum albumin. The other three lines appeared to show identity with lines formed by other serum components. The presence of albumin was confirmed by the use of anti-(guinea-pig serum albumin), but it was found to constitute not more than a small part of fraction I. After reaction of fraction $I$ with anti-fraction $I$, eight or nine precipitin lines have always been observed. A single preparation of this antiserum has been used throughout the work described in this paper, but qualitatively similar results have been obtained with an antiserum from another rabbit. All of the precipitin lines formed by fraction I appeared to give reactions of identity with lines produced by components of guinea-pig serum, except for one very faint line which was seen in only one experiment. On the other hand, guinea-pig serum formed two or possibly even four lines which did not join with any of the lines formed by fraction I. Neither the antiserum in question nor guinea-pig serum gave lines on reaction with $0.9 \%$ sodium chloride.

Electrophoresis and immunoelectrophoresis. Electrophoresis on cellulose acetate at pH 8.6 (Fig. 2) showed that most of the material in fraction $I$ travelled as a single band which had a mobility similar to guinea-pig serum $\alpha$-globulins of faster mobility. A small amount of material which corresponded to $\alpha$-globulins of slower mobility was also present together with a trace of material corresponding to serum albumin. The $\alpha$-globulins stained strongly for carbohydrate. On starch-gel electrophoresis with the $\mathrm{pH} 9$ buffer system (Fig. 2), most of the material travelled as a single band which had a mobility similar to that of serum albumin. As discussed elsewhere, albumin does not 


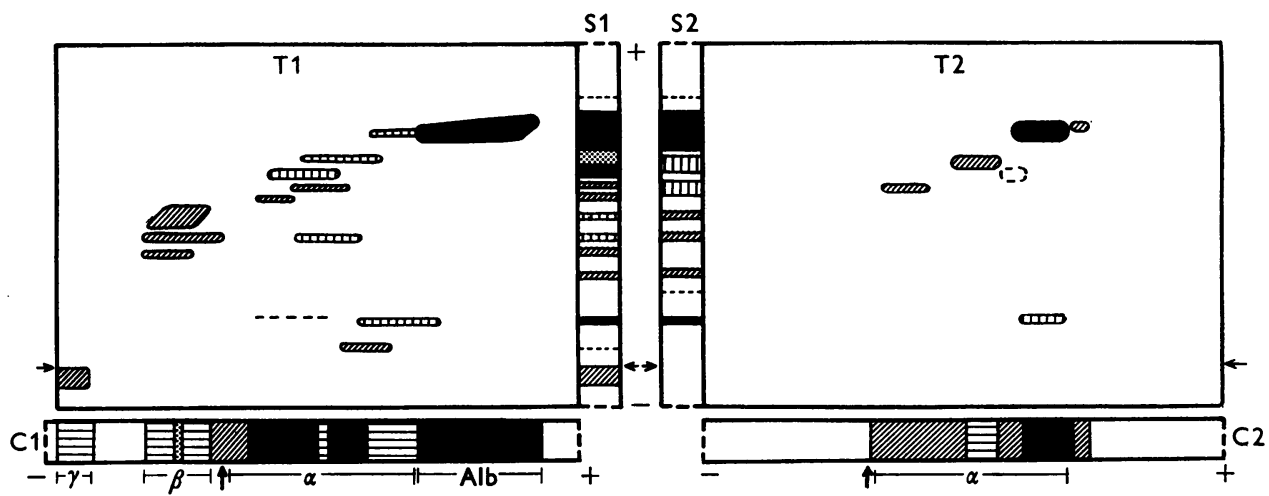

Fig. 2. Electrophoresis of guinea-pig serum and fraction I: C1 and C2 respectively, on cellulose acetate with veronal buffer, $\mathrm{pH} 8.6$; $\mathrm{S} 1$ and $\mathrm{S} 2$ respectively, with starch gel and the pH 9 buffer system; T1 and T2 respectively, two-dimensional electrophoresis with cellulose acetate followed by starch gel, the buffers used being as above. The diagrams are drawn in such a way that direct comparison can be made between $\mathrm{Cl}$ and C2 and between S1 and S2. Alb, Serum albumin; $\alpha, \beta$ and $\gamma, \alpha$-, $\beta$ - and $\gamma$-globulin respectively; the position occupied by the $\alpha$-globulin region is also shown beneath C2. Samples were applied at positions indicated

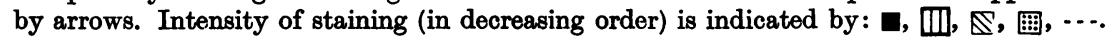

form a large part of the material present in this band. Five minor bands were also always detected, the slowest of which corresponded in mobility to the so-called slow $\alpha_{2}$-macroglobulin of human serum (Smithies, 1955; Poulik \& Smithies, 1958). A pre-albumin component and a band with a mobility slightly greater than that of the slowest component have been observed with heavily loaded gels. None of the bands stained for lipid.

Two-dimensional electrophoresis (Fig. 2) gave little additional resolution of the material forming the major part of fraction I, but the results provide further evidence that this material is distinct from serum albumin. Trace components are not detected because of the difficulty of applying a large sample to the cellulose acetate. The technique also showed that the band of slowest mobility on starch-gel electrophoresis with the $\mathrm{pH} 9$ system behaves as an $\alpha$-globulin on cellulose acetate at pH 8.6 and might thus be regarded as an $\alpha$-macroglobulin. On two-dimensional electrophoresis of guinea-pig serum (Fig. 2), a band which had similar electrophoretic properties to the main band of fraction I was observed; a correspondence in behaviour between components of fraction $I$ and constituents of guinea-pig serum could also be seen in several other instances, such as that of the presumed $\alpha$-macroglobulin component. The results obtained with guinea-pig serum show many resemblances to those found by Riou, Paoletti \& Truhaut (1962), who used paper as medium for the first dimension; such differences as occur might be explained by the use of different conditions.

Further information on the composition of fraction I was obtained by immunological analysis

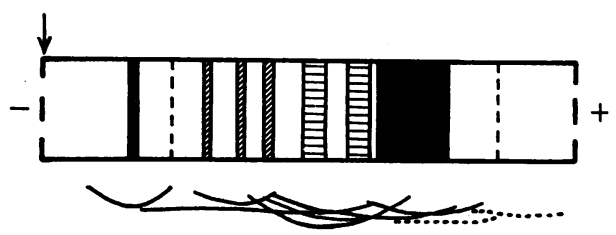

Fig. 3. Starch-gel electrophoresis of fraction I with the pH 9 buffer system followed by reaction with anti-fraction $I$. Faint precipitin lines at the lower part of the Figure are indicated by broken lines.

with anti-fraction I after electrophoresis with either cellulose acetate or starch gel. The main band obtained by electrophoresis with either medium corresponded to two precipitin lines; with starch gel (Fig. 3), a faint third line was seen in one of three experiments. The results obtained with starch gel as electrophoretic medium were confirmed by examination of isolated segments of gel corresponding to the main band and of a concentrated eluate of such segments. Thus the eluate formed one faint and two distinct lines, all of which gave reactions of identity with lines produced by fraction I on double-diffusion analysis. Although anti-fraction I contains antibody to guinea-pig serum albumin, neither of the two distinct lines observed under these conditions appeared to be formed by precipitation of albumin. Six other precipitin lines were always observed on starch-gel immunoelectrophoresis of fraction I and a further faint line was seen in the pre-albumin region in two of three experiments. The pattern of precipitin lines obtained on starch-gel immuno- 
electrophoresis of guinea-pig serum was essentially similar to that found for fraction $I$.

On starch-gel electrophoresis at $\mathrm{pH} 6 \cdot 0$ or $4 \cdot 4$, most or all of the material present in fraction I travelled as a single band, but at $\mathrm{pH} 3.4$ four main and a number of minor bands were found (Fig. 4). The latter finding suggested that the main band found with the pH 9 system (Fig. 2) would resolve into a number of bands if subjected to electrophoresis at $\mathrm{pH} 3 \cdot 4$, and such a result was in fact obtained on examination of an eluate of gel corresponding to the main band (Fig. 4). The results obtained at these three $\mathrm{pH}$ values suggested that, with the possible exception of a small number of minor constituents, the components of fraction I have relatively low isoelectric points. This suggestion was confirmed by the results of electrophoresis on cellulose acetate with a series of citratephosphate buffers. Most of the material of fraction I showed zero mobility at about $\mathrm{pH} 3.5$ in relation to dextran.

Results described below show that fraction I contains sialic acid. Sialic acid is responsible for the low isoelectric point of a number of comparable serum glycoproteins of other species, such as orosomucoid (e.g. Popenoe \& Drew, 1957) and fetuin (Spiro, 1960). Fraction I was heated with $0.025 \mathrm{~N}$ sulphuric acid at $85^{\circ}$ for $60 \mathrm{~min}$.; the hydrolysate was then extensively dialysed against water and concentrated to small volume by ultrafiltration. It was found that no more than a trace of sialic acid could remain after this treatment, but little or no other material is released (see below). The product obtained was examined by electrophoresis on cellulose acetate at $\mathrm{pH} 8 \cdot 6$ and $\mathrm{pH} 4 \cdot 0$. The results obtained were consistent with the supposition that sialic acid residues are at least in part responsible for the relatively low isoelectric points possessed by components of fraction $\mathrm{I}$.

Ultracentrifuge analysis. When fraction I was examined at $\mathrm{pH} 8 \cdot 4, I 0 \cdot 21$, by the sedimentation velocity method, two peaks were observed, the slower one of which had a much greater area than

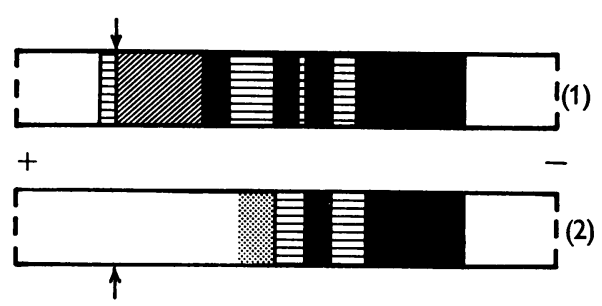

Fig. 4. Starch-gel electrophoresis with citrate buffer, $\mathrm{pH} 3 \cdot 4$, of: (1) fraction I, and (2) eluate from region of main band found on starch-gel electrophoresis of fraction I with the $\mathrm{pH} 9$ buffer system (Fig. 2). the faster. With solutions which contained approximately $1.0,0.9$ and $0.3 \%$ of fraction $I$, the $S_{20 \text {,w }}$ values of the slower peak were $3 \cdot 2,3 \cdot 2$ and $3 \cdot 5 \mathrm{~s}$ respectively, and of the faster peak, 16.6, 16.6 and $17 \cdot 5 \mathrm{~s}$ respectively. The faster peak presumably represents the component which has the electrophoretic properties of a $\alpha$-macroglobulin, since the $S_{20, \text { w }}$ found is rather similar to values reported for human $\alpha_{2}$-macroglobulin preparations (for references, see Winzler, 1960). The solution that contained $1.0 \%$ of fraction $I$ was investigated further by two procedures. Examination of results obtained with a synthetic boundary cell showed that the area of the larger peak found during sedimentation velocity analysis decreased during sedimentation in relation to the area of the peak found in the synthetic boundary cell; the former peak had an area of $90 \%$ and $84 \%$ of the latter after 39 and $70 \mathrm{~min}$. sedimentation respectively, correction being made for radial dilution. This finding indicates that fraction $I$ is somewhat more heterogeneous than is apparent from the results of sedimentation velocity analysis. The inverse square of the height of the peak found in the synthetic boundary cell varied in a linear manner with time. An apparent diffusion coefficient, $D_{20, w}$ of $5 \cdot 6 \times 10^{-7} \mathrm{~cm}^{2}$ sec. $^{-1}$ was obtained. The molecular weight of the material present in the larger peak found on sedimentation velocity analysis was calculated to be approximately $4.8 \times 10^{4}$ on the basis of the values given above for $S_{20, \mathrm{w}}$ and $D_{20, \mathrm{w}}$ which were obtained with a $1.0 \%$ solution of fraction $I$; a partial specific volume of 0.700 was assumed on the basis of results obtained with fetuin (Spiro, 1960). This estimate for molecular weight will be slightly too high because the diffusion coefficient used for calculation was that obtained for fraction I as a whole and not that for the material in question. When fraction I was examined by the method of Archibald, the weight-average molecular weight changed slightly at the top and bottom menisci during the course of sedimentation, a finding which indicates some heterogeneity. At the top meniscus, values for mol.wt. of $6 \cdot 0,5 \cdot 5$ and $5 \cdot 4 \times 10^{4}$ were obtained after 18,34 and $66 \mathrm{~min}$. respectively centrifuging at $7247 \mathrm{rev} . / \mathrm{min}$.; the corresponding values at the bottom meniscus were $5 \cdot 8,6 \cdot 2$ and $6.9 \times 10^{4}$ respectively.

Comparison of fraction I from individual guinea pigs. Samples of fraction I were prepared from the separately collected serum of five guinea pigs and from a pool of all five sera and compared by starchgel electrophoresis at $\mathrm{pH} \mathrm{3.4}$ and by doublediffusion analysis with anti-fraction I. Electrophoresis did not show any qualitative difference between the samples whereas immunological analysis showed that no more than minor qualitative differences could exist between them. 
Solubility of fraction $I$ in perchloric acid and examination of perchloric acid-soluble protein fraction

Most of the components of fraction I were found to possess solubility characteristics with respect to certain strong acids which are similar to some comparable serum glycoproteins, such as orosomucoid (e.g. Winzler, 1960) and fetuin (Spiro, 1960). Thus, with $0 \cdot 5-1 \%$ solutions of fraction $I$, it was found that all but a few per cent of the material present is soluble in $0.6 \mathrm{M}$-perchloric acid or $0.3 \mathrm{M}$-trichloroacetic acid; fraction $I$ is, however, insoluble in phosphotungstic acid $(3 \%, \mathrm{w} / \mathrm{v}$, in $1 \cdot 2 \mathrm{~N}-\mathrm{HCl})$.

The importance of components of fraction I as constituents of the perchloric acid-soluble protein fraction of guinea-pig serum (i.e. the total nondiffusible material soluble in $0 \cdot 6 \mathrm{M}$-perchloric acid) was investigated. On electrophoresis on cellulose acetate at pH 8.6 (Fig. 5) most of the material of the fraction travelled at a rate similar to $\alpha$ globulins of faster mobility. There was also material which corresponded to $\alpha$-globulins of slower mobility, some which corresponded to $\beta$-globulins and a trace which was similar to albumin. All of the material which stained for protein also stained for carbohydrate. On starch-gel electrophoresis with the pH 9 system (Fig. 5), one faint and five heavy bands were found; one of the heavy bands had a mobility similar to that of serum albumin, whereas all of the other bands were of lower mobility. A faint pre-albumin band was detected in one experiment with a heavily loaded gel. Two-dimensional electrophoresis (Fig. 5) shows that at least most of the material with mobility similar to that of albumin with starch gel behaves as a $\alpha$-globulin of faster mobility on cellulose acetate at $\mathrm{pH} 8.6$ and is thus similar to the major part of the material forming fraction I (see above). Although albumin is present in the perchloric acid-soluble protein fraction (see below), the amount of it is too small to be detected by the method used for two-dimensional electrophoresis. The results thus suggest that some part of the perchloric acid-soluble protein fraction is made up of proteins present in fraction I; a large proportion of it might, however, be formed of other proteins. Evidence in support of these suggestions was obtained by immunological analysis and fractionation with carboxymethylcellulose.

The number of precipitin lines detected on reaction of the perchloric acid-soluble protein fraction with various antisera was as follows: anti-(guineapig serum albumin), one; anti-(guinea-pig serum), five; anti-fraction I, four; anti-(perchloric acidsoluble protein fraction), at least eight. All of the precipitin lines formed with these antisera appeared to show reactions of identity with lines formed by components of guinea-pig serum. These and other results indicate that not all of the components of fraction I are present in detectable amounts in the perchloric acid-soluble protein fraction, and that the latter contains constituents which are not components of fraction I. About $20 \%$ of the perchloric acid-soluble protein fraction was not adsorbed by carboxymethylcellulose (Fig. 6) and thus resembled fraction I. There was little or no material which corresponded to fraction 2 found when guinea-pig serum is chromatographed under similar conditions. The unadsorbed material gave a pattern similar to that obtained with fraction I on electrophoresis on cellulose acetate at $\mathrm{pH} 8 \cdot 6$. On starch-gel electrophoresis with the $\mathrm{pH} \mathrm{9.0}$ system four bands were found, the major one of which had a mobility similar to that of serum albumin, and

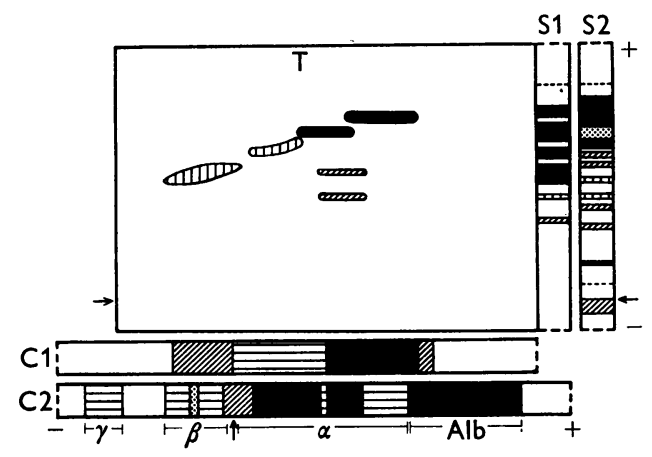

Fig. 5. Electrophoresis of the perchloric acid-soluble protein fraction and guinea-pig serum: $\mathrm{C} 1$ and $\mathrm{C} 2$ respectively, on cellulose acetate at $\mathrm{pH} \mathrm{8.6;} \mathrm{S} 1$ and $\mathrm{S} 2$ respectively, with starch gel and $\mathrm{pH} 9$ buffer system. T, Two-dimensional electrophoresis of the perchloric acidsoluble protein fraction with cellulose acetate followed by starch gel; the buffers used were as above. Alb, Serum albumin; $\alpha, \beta$ and $\gamma, \alpha$-, $\beta$ - and $\gamma$-globulin respectively.

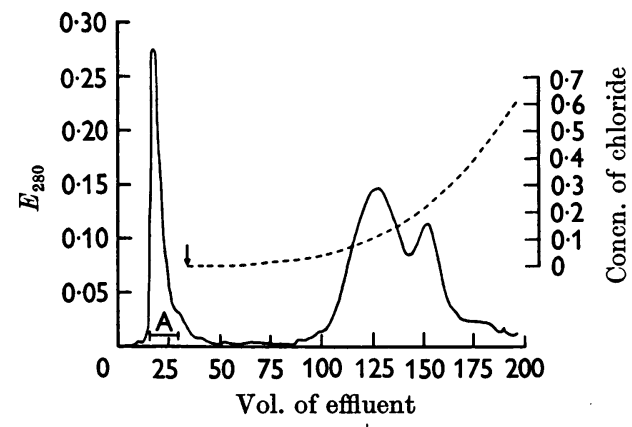

Fig. 6. Chromatography of the perchloric acid-soluble protein fraction on carboxymethyl-cellulose. Elution was brought about by $50 \mathrm{~mm}$-acetate buffer, $\mathrm{pH} 5 \cdot 0$, and, after connexion at arrow, by a gradient of $\mathrm{NaCl}$ dissolved in this buffer (see the text). Fractions of $2 \cdot 2 \mathrm{ml}$. were collected. Fractions corresponding to $A$ were taken as the unadsorbed material (see the text). 
on reaction with anti-fraction I six precipitin lines were seen.

Because it is known that contact of a glycoprotein, such as orosomucoid, with perchloric acid can result in a decrease of electrophoretic mobility, particularly if exposure is prolonged (e.g. de Vaux St Cyr, Courcon \& Grabar, 1958), the possibility was investigated that some of the material present in the perchloric acid-soluble protein fraction might represent products formed by the action of perchloric acid on components of fraction I. Examination by starch-gel electrophoresis and analysis with anti-fraction I of fraction I exposed to perchloric acid provided evidence that such altered components do not form an appreciable part of the perchloric acid-soluble protein fraction.

\section{Chemical analysis of fraction $I$}

Hydrolysis with Dowex 50-hydrochloric acid and subsequent fractionation. Experiments were carried out to find conditions which result in maximum release of sugars with minimum destruction after liberation. The conditions investigated were suggested by the work of Anastassiadis \& Common (1958) and Haab \& Anastassiadis (1961). A comparison was first made of the extent of hydrolysis produced by heating fraction I with Dowex 50 $\left(\mathrm{H}^{+}\right.$form) and either $0.04 \mathrm{~N}$ - or $0.25 \mathrm{~N}$-hydrochloric acid for various periods of time. Control mixtures of galactose, mannose, glucosamine and bovine serum albumin (see the Experimental section) were concurrently subjected to hydrolysis and fractionation and the results obtained were used to make corrections for the total losses resulting from these procedures. The rate of liberation of galactose, mannose and hexosamine was much greater with $0.25 \mathrm{~N}$-hydrochloric acid than with $0.04 \mathrm{~N}$-hydro- chloric acid. With $0 \cdot 25 \mathrm{~N}$-hydrochloric acid the results obtained after heating for $15 \mathrm{hr}$. or $36 \mathrm{hr}$. were similar. With $0.04 \mathrm{~N}$-hydrochloric acid the values obtained gradually approached those found with $0 \cdot 25 \mathrm{~N}$-hydrochloric acid, but even after $36 \mathrm{hr}$. the values for galactose and mannose were about $15 \%$ less than the maximum found with $0.25 \mathrm{~N}$ hydrochloric acid; the value for hexosamine was, however, only a few per cent less than the maximum reached with the stronger acid. The total volume of hydrolysis mixtures used in the above work was $0.85 \mathrm{ml}$. (see the Experimental section). The effect of reduction of volume to $0.60 \mathrm{ml}$. was investigated; $0 \cdot 25 \mathrm{~N}$-hydrochloric acid was used and the period of heating was $36 \mathrm{hr}$. The glucosamine value so obtained was similar to that found with $0.85 \mathrm{ml}$. volume, but the values for galactose and mannose were 7 and $12 \%$ higher respectively. These high values may result from over-correction for the amount of hexose destroyed subsequently to liberation, since the recovery of galactose and mannose from a control mixture was appreciably lower ( 80 and $76 \%$ respectively) than that found with the larger volume (91 and $94 \%$ respectively). The results obtained thus indicate that heating with Dowex 50 and $0.25 \mathrm{~N}$-hydrochloric acid for $30-36 \mathrm{hr}$. under conditions similar to those of the first-mentioned experiments above should provide a satisfactory procedure for the liberation of the hexoses and hexosamine of fraction I. This period of heating was chosen, although it appeared to be in excess of that required (see above), to make allowance for variations that might arise from the use of a two-phase system. Evidence that satisfactory values for hexoses are obtained with this method is provided by the finding that the sum of the values thereby obtained for galactose and

Table 1. Composition of fraction I and perchloric acid-soluble protein fraction from guinea-pig serum

Values are given in relation to protein as determined by the method of Lowry et al. (1951). The protein content of fraction I was $78 \mathrm{~g} . / 100 \mathrm{~g}$. dry wt. (two determinations). Number of determinations is given in parentheses. Sialic acid was determined by : $(a)$ the periodate-thiobarbituric acid method; $(b)$ the Dowex 2 -resorcinol method.

\begin{tabular}{|c|c|c|c|}
\hline & \multicolumn{2}{|c|}{ Fraction I } & \multirow{2}{*}{$\begin{array}{c}\text { Perchloric acid- } \\
\text { soluble protein } \\
\text { fraction } \\
\text { (g./100 g. of protein })^{*}\end{array}$} \\
\hline & $\begin{array}{l}\text { (g. } / 100 \mathrm{~g} . \\
\text { of protein)* }\end{array}$ & $\begin{array}{c}\text { (m-moles/100 } \mathrm{g} . \\
\text { of protein) }\end{array}$ & \\
\hline Total hexose & $9 \cdot 6$ & $53(4)$ & $9 \cdot 7(3)$ \\
\hline Galactose & $4 \cdot 8$ & $27(5)$ & $4 \cdot 4(1)$ \\
\hline Mannose & $4 \cdot 8$ & $27(5)$ & $4.9(1)$ \\
\hline Fucose $†$ & $0 \cdot 2$ & $1 \cdot 2(3)$ & $0.1(1)$ \\
\hline Hexosamine & $6 \cdot 7 \ddagger$ & $37(6)$ & $6 \cdot 7(2)$ \\
\hline Uronic acid & 0.09 & $0.5(1)$ & - \\
\hline Sialic acid $\S(a)$ & $6 \cdot 9$ & $22(2)$ & $6 \cdot 5(1)$ \\
\hline Sialic acid $\S(b)$ & $6 \cdot 5$ & $21(1)$ & $6 \cdot 1(1)$ \\
\hline$O$-Acetyl & $1 \cdot 1$ & $19(1)$ & - \\
\hline Total acetyl & $4 \cdot 7$ & $80(2)$ & - \\
\hline $\begin{array}{l}* \text { Unc } \\
\dagger \text { See } \\
\ddagger 8 \cdot 3 \\
\S \mathrm{As}\end{array}$ & or uptake o & $\begin{array}{l}\text { r on hydrolysis. } \\
\text { tylhexosamine } \\
\text { e, however, text. }\end{array}$ & text). \\
\hline
\end{tabular}


mannose is equal to the value obtained for total hexose by direct application of the orcinol method to fraction I (Table 1). The recoveries of sugars from control mixtures which were subjected to similar conditions followed by fractionation and analysis were (average of 10 values in each case): galactose, $93 \pm$ s.E. $2 \%$; mannose, $92 \pm 3 \%$; glucosamine, $93 \pm 1 \%$. In an experiment in which glucuronic acid was included in a control mixture $88 \%$ of it was recovered. The corrections applied for destruction and losses are therefore small.

Carbohydrate constituents of fraction I. Only galactose and mannose were detected in the neutral sugar fraction. A very small reaction for fucose was obtained when the cysteine-sulphuric acid method of Dische \& Shettles (1948) was applied to fraction I. The presence of large quantities of galactose and mannose makes it difficult to establish the significance of this reaction and also results in the test of Dische \& Shettles (1951) were rather inconclusive. Further, it is difficult to make an accurate correction for non-specific reaction under the conditions obtaining. Only glucosamine was detected in the hexosamine fraction. Evidence was obtained for the presence of uronic acid.

When the sialic acid fraction isolated after hydrolysis for 35 or $60 \mathrm{~min}$. with $0.05 \mathrm{~N}$-sulphuric acid was examined by paper chromatography, $\mathrm{N}$-acetylneuraminic acid was detected but little or no $N$-glycollylneuraminic acid. Except in some experiments, in which hydrolysis had been carried out for 60 min., a spot with a mobility greater than $N$-acetylneuraminic acid was detected by the periodate-thiobarbituric acid detection system used. With solvents $B$ and $C$ this spot had in general an elongated form, the exact shape varying from experiment to experiment and according to the solvent used. It had a mobility which was approximately similar to that of $\mathrm{N}$-acetyl-4- $\mathrm{O}$ acetylneuraminic acid with solvents $\mathrm{C}$ and $\mathrm{E}$, but with solvent $B$ the spot included both material with mobility similar to the 4-O-acetyl compound and material with higher or lower mobility. The 4-O-acetyl compound subjected to heating with acid under conditions similar to those used for hydrolysis did not behave in exactly the same way as the material in question on chromatography with solvent B. This spot did not appear when $N$-acetylneuraminic acid was heated with a mixture of galactose, mannose, $\mathrm{N}$-acetylglucosamine and bovine serum albumin under conditions similar to those used for hydrolysis. The diffusate obtained on dialysis of an hydrolysate produced by heating fraction I with $0.05 \mathrm{~N}$-sulphuric acid at $90^{\circ}$ for $60 \mathrm{~min}$. contained only traces of orcinol- and ninhydrin-positive material, and the non-retarded (higher molecular weight) material obtained by fractionation of such an hydrolysate with Sephadex
G-25 contained a similar content of galactose, mannose and hexosamine in relation to protein as fraction I itself. There is therefore no appreciable loss of these sugars as a result of exposure to the conditions used for liberation of sialic acid.

To investigate further the possible occurrence of a $O$-acyl derivative of $N$-acetylneuraminic acid, the nature of the sialic acid liberated by treatment of fraction I with neuraminidase was investigated. For study of the product released, a freshly prepared solution of $3 \mathrm{mg}$. of fraction I was treated with neuraminidase as described under Fig. 7; about $55 \%$ of the sialic acid present was released. On chromatography with Dowex 2 (formate form), most of the material liberated was eluted by $0.1 \mathrm{~N}$ formic acid; the volume required for elution was similar to that required to elute $\mathrm{N}$-acetyl-4- $\mathrm{O}$ acetylneuraminic acid. No sialic acid was detected on elution with $0.3 \mathrm{~N}$-formic acid; this concentration of formic acid elutes $N$-acetylneuraminic acid. The eluted sialic acid was examined by paper chromatography with solvent $B$ and a compact spot was found which had a mobility identical with that of the 4- $O$-acetyl compound. Fraction I also formed an hydroxamate when allowed to react with hydroxylamine; on paper chromatography, the product formed had a mobility similar to that of acetyl hydroxamate.

When fraction I was treated with a crude preparation of neuraminidase, sialic acid was rapidly liberated (Fig. 7), but unless special procedures (see below) were adopted, no more than $55-60 \%$ of the total sialic acid was released. Increase in the release of sialic acid could be brought about in two ways. The first method involved dialysis and addition of further neuraminidase during incubation. For example, a mixture which contained $4.5 \mathrm{mg}$. of fraction I/ml., $0.45 \mathrm{ml}$. of neuraminidase/ $\mathrm{ml}$. and calcium acetate buffer was incubated in a dialysis sac immersed in the same buffer. After $2 \mathrm{hr}$. the buffer outside the sac was changed and $0.5 \mathrm{hr}$. later one-third of the amount of neuraminidase originally taken was added to the sac and incubation continued for a further $2.5 \mathrm{hr}$. About $80 \%$ of the total sialic acid was released in experiments of this type. Analysis of fraction I treated in such a manner showed that no appreciable loss of galactose, mannose or hexosamine occurred on incubation with the enzyme preparation. The second procedure was suggested by the work of Faillard (1959), who found that sialic acid was released more readily by neuraminidase from bovine submaxillary mucin if the latter had been treated with dilute alkali before incubation, a procedure which removes $O$-acetyl groups from the $N$-acetyl-7$O$-acetylneuraminic acid present. The experimental procedure used (see Fig. 7) was based on the results of a model experiment in which it was found that, 
as judged by hydroxamate formation (Hestrin, 1949 ), about $80 \%$ of the $O$-acetyl groups of $N$. acetyl-4-O-acetylneuraminic acid were removed on standing the latter in solution $(0.4 \mathrm{mg} . / \mathrm{ml}$.) at pH 9.5 at $2^{\circ}$ for $16 \mathrm{hr}$. After exposure of fraction I to similar conditions, neuraminidase released about $80 \%$ of the total sialic acid (Fig. 7).

The results of quantitative analyses of fraction I are given in Table 1. The value given for fucose must be treated with caution in view of reservations made above. There is reasonably good agreement between the values for sialic acid obtained by the periodate-thiobarbituric acid and resorcinol methods, which suggests that little or no $N$-acetyl7-O-acetylneuraminic acid is present as this compound would be estimated by the resorcinol method but not by the thiobarbituric acid method. Further, this finding together with the known behaviour of various derivatives of neuraminic acid in the methods of analysis used (Aminoff, 1961; Svennerholm, 1957) suggests that, although fraction I may contain an $O$-acyl derivative of $N$-acetylneuraminic acid, little error should result from the use of $N$-acetylneuraminic acid as standard during analyses. The period of heating used for hydrolysis in quantitative work $(60 \mathrm{~min}$.) was based on a study using the Dowex 2-resorcinol method of following the time-course of liberation of sialic acid. The recovery of $N$-acetylneuraminic acid from control mixtures subjected to similar conditions was about $96 \%$.

The material estimated by the method used for determination of total acetyl was shown to be acetyl by isolation of the hydroxamate formed and subsequent paper chromatography. With the

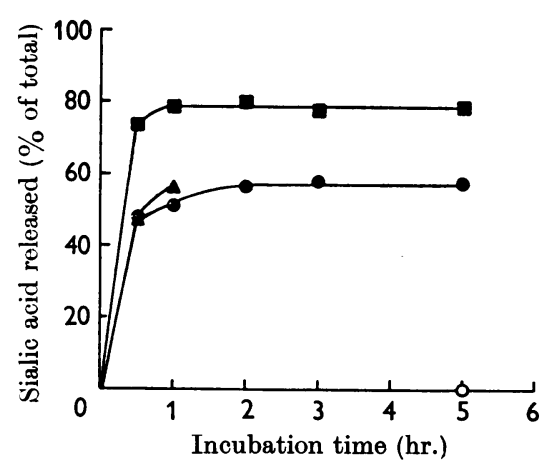

Fig. 7. Action of neuraminidase on fraction I after storage of the latter in solution for $16 \mathrm{hr}$. at $-20^{\circ}(O), 2^{\circ}(\Delta)$ or $2^{\circ}$ at $\mathrm{pH} 9.5(\square)$; material kept at $-20^{\circ}$ was also incubated without enzyme (O). Incubation mixtures contained $1.5 \mathrm{mg}$. of fraction $\mathrm{I} / \mathrm{ml}$,, $0.5 \mathrm{ml}$. of neuraminidase preparation $/ \mathrm{ml}$. and tris-maleate- $\mathrm{CaCl}_{2}$ buffer, $\mathrm{pH} 5.6$ (see text). Total sialic acid was determined by hydrolysis with acid followed by the periodate-thiobarbituric acid method (see the text). solvent system used (Thompson, 1951), it was found that glycollyl hydroxamate was resolved from formyl and acetyl hydroxamates $\left(R_{F} 0 \cdot 38\right.$, 0.49 and 0.58 respectively). Table 1 shows that there is approximately 1 mole of $O$-acetyl group present for each mole of sialic acid. It thus seems that most or all of the sialic acid of fraction I may exist in the form of a diacetyl derivative of neuraminic acid. If the values for $N$ - and $O$-acetyl groups associated with sialic acid are subtracted from the value obtained for total acetyl, the remainder shows a molar ratio of approximately 1.0 in relation to the amount of hexosamine present. Since some $N$-acetylhexosamine can be detected in partial acid hydrolysates of fraction I (unpublished work), this suggests that most or all of the hexosamine residues present in fraction I occur as the $N$-acetyl derivative.

The total carbohydrate content of fraction I was calculated to be approximately $19 \%$ of dry weight, corrections being made for uptake of water on hydrolysis and the assumptions made that hexosamine exists entirely as the $N$-acetyl derivative and sialic acid occurs entirely as diacetylneuraminic acid. The sum of the values obtained for total carbohydrate and protein (Table 1) therefore account for about $97 \%$ of dry weight.

\section{Carbohydrate constituents of perchloric acid-soluble protein fraction}

Only galactose and mannose were detected in the neutral sugar fraction by paper electrophoresis with borate or arsenite buffers and paper chromatography with solvent $A$ and detection reagent (1) and solvent D and reagents (2), (3) and (4). A very small reaction for fucose was obtained with the cysteine-sulphuric acid method (Dische \& Shettles, 1948). The same reservations concerning the occurrence of fucose must therefore hold as apply to fraction I. The hexosamine fraction yielded arabinose on oxidation with ninhydrin and $N$-acetylglucosamine on acetylation, indicating that the hexosamine present is largely or entirely glucosamine. Examination by paper chromatography with solvents $B$ and $E$ of the sialic acid fraction obtained by hydrolysis with $0.05 \mathrm{~N}$ sulphuric acid for 35 or $60 \mathrm{~min}$. and fractionation with Dowex 2 (formate form) showed that little or no $N$-glycollylneuraminic acid was present. $N$ Acetylneuraminic acid was detected together with some material which had a greater mobility than $N$-acetylneuraminic acid. The results of quantitative analyses are given in Table 1.

\section{DISCUSSION}

Although fraction I clearly does not represent a homogeneous glycoprotein, nevertheless a large 
proportion of it is composed of substances which show a very close similarity in certain physical properties. For example, the material forming the major part of fraction $I$ is soluble in perchloric acid, at least a large part of it sediments at a similar rate in the ultracentrifuge at $\mathrm{pH} \mathbf{8 \cdot 6}$, and it is eluted from DEAE-cellulose by a relatively small increase in concentration of eluent at $\mathrm{pH} 6 \cdot 6,7 \cdot 6$ or 8.4 (unpublished work). It is not resolved by starchgel electrophoresis at $\mathrm{pH} 4 \cdot 4, \mathrm{pH} 6 \cdot 0$ or approximately $\mathrm{pH} \mathrm{9,} \mathrm{or} \mathrm{by} \mathrm{two-dimensional} \mathrm{electro-}$ phoresis in conjunction with cellulose acetate at the latter pH. The material, however, separates into a number of bands on starch-gel electrophoresis at $\mathrm{pH} 3 \cdot 4$, and it forms two or three precipitin lines on reaction with anti-fraction $I$. The resolution at $\mathrm{pH} 3.4$ might reflect the separation of components which have different immunological properties. The results do not exclude the possibility that a number of components with different electrophoretic properties but which have similar immunological characteristics are present (cf. orosomucoid: Schmid, Binette, Kamiyama, Pfister \& Takahashi, 1962).

The remainder of fraction $I$ is composed of perhaps as many as ten components, some of which form an extremely small part of the total material. Although these components can be distinguished from the major part of fraction $I$ on the basis of electrophoretic mobility under certain conditions and immunological characteristics, they nevertheless may possess some similar properties to it. For example, most of the components of fraction I have a relatively low isoelectric point, many are not resolved to any appreciable extent by starchgel electrophoresis at $\mathrm{pH} 4 \cdot 4$ or $6 \cdot 0$, and most are soluble in perchloric acid. Further, although it is possible to achieve some separation of components of fraction I by chromatography on DEAEcellulose under appropriate conditions, the components do not differ very markedly in chromatographic properties with respect to this: exchanger (unpublished work).

Various lines of evidence strongly suggest that at least many of the components of fraction I represent components of guinea-pig serum which have not been altered in physical or immunological properties to an appreciable extent as a result of the procedure used for isolation of fraction $I$.

The physical characteristics of the predominant constituents of fraction I show a general similarity to those of some carbohydrate-containing acidic serum $\alpha$-globulins of other species such as human orosomucoid and bovine fetuin (e.g. Winzler, 1960; Spiro, 1960). For example, the estimate obtained for the molecular weight of a large part of fraction I is close to the values reported for the molecular weight of orosomucoid and fetuin. Guinea-pig serum appears to contain an $\alpha$-macroglobulin which resembles human $\alpha_{2}$-macroglobulin preparations in mobility on starch-gel electrophoresis (Poulik \& Smithies, 1958) and sedimentation coefficient (e.g. Winzler, 1960). Human $\alpha_{2}$-macroglobulin contains carbohydrate (e.g. Winzler, 1960). Guinea-pig serum contains, however, at most very little of a component that is directly comparable with human orosomucoid in that it behaves as a pre-albumin on starch-gel electrophoresis at approximately $\mathrm{pH} 9$ (for behaviour of human serum, see, e.g., Poulik \& Smithies, 1958). The failure to detect appreciable amounts of a pre-albumin in guinea-pig fraction I (or fraction II; unpublished work) does not appear to result from anomalous behaviour of the procedure used for isolation of fraction $I$, since a fraction isolated from human serum by means of a similar procedure contained a prominent prealbumin band corresponding to orosomucoid.

Fraction I also shows general resemblance in carbohydrate composition to comparable glycoproteins of other species (e.g. Winzler, 1960). It has not been conclusively established that fucose is present in fraction I. On the basis of the estimated average molecular weight of fraction $I$, the apparent values for fucose and uronic acid represent less than $1 \mathrm{~mole} / \mathrm{mole}$ of protein. These substances might therefore only be constituents of certain components of fraction $I$.

Evidence has been presented that at least a large part of the sialic acid of fraction I occurs in the form of an $O$-acetyl derivative of $N$-acetylneuraminic acid, possibly $\mathrm{N}$-acetyl-4-O-acetylneuraminic acid. The $O$-acetyl groups of derivatives of $N$-acetylneuraminic acid are rapidly lost on exposure to the conditions of acid hydrolysis used for liberation of sialic acid (e.g. Blix et al. 1956). There is evidence (Blix \& Lindberg, 1960) that an intermediate compound is formed during the conversion of $\mathrm{N}$-acetyl-7-O-acetylneuraminic acid into $N$ acetylneuraminic acid, and it is possible that a similar situation might obtain with the $O$-acetyl compound found in fraction $I$. The fact that the 4- $O$-acetyl compound subjected to the conditions used for hydrolysis did not behave on paper chromatography in exactly the same way as the material released from fraction I does not completely exclude the presence of this compound in fraction $I$ in view of the difficulty of reproducing in model experiments conditions which are similar to those which exist during hydrolysis of a glycoprotein. The best evidence for the occurrence of an $O$-acetyl derivative comes from the results of examination of the material released by neuraminidase. At least most of the sialic acid released behaved in a similar way to the 4-O-acetyl compound on ion-exchange and paper chromatography. Under the conditions used in this experiment, only about $55 \%$ of the total sialic acid was liberated. 
The results of analysis for $O$-acetyl groups suggested that most or all of the sialic acid present may exist as an $O$-acetyl derivative. The results obtained with neuraminidase indicate that at least most of the sialic acid residues occupy terminal positions and suggest that they are joined by C-2 to another sugar residue by means of an $\alpha$-oxo linkage (see, for example, Gottschalk, 1960). Other evidence that sialic acid residues are terminal comes from the finding that sialic acid can be released by hydrolysis with dilute acid without any appreciable loss of other sugar residues. Further, sialic acid residues are rapidly oxidized on treatment of fraction I with periodate (unpublished work). Sialic acid residues also occupy terminal positions in a number of other serum proteins (e.g. Popenoe \& Drew, 1957; Spiro, 1960).

While it has not yet been established that, apart from the small amount of albumin present, all of the components of fraction I are glycoproteins, evidence obtained by electrophoresis on cellulose acetate at various $\mathrm{pH}$ values and chromatography on DEAE-cellulose (unpublished work) shows that a number of the components must be glycoproteins.

The carbohydrate composition of the perchloric acid-soluble protein fraction is rather similar to that of fraction I (Table 1). Whether this resemblance is a fortuitous one and merely represents a similar average value for two groups of glycoproteins or, rather, is a reflexion of some underlying structural regularity amongst a number of glycoproteins present in guinea-pig serum remains to be determined by future work.

Although the perchloric acid-soluble protein fraction isolated from guinea-pig serum is similar to that from human serum (e.g. de Vaux St Cyr et al. 1958; Biserte, Havez \& Hayem-Levy, 1960; de Vaux St Cyr, 1960; Winzler, 1960) in that it consists of $\alpha$ - and $\beta$-globulins together with a small amount of albumin, and has a relatively high content of carbohydrate, it nevertheless shows appreciable differences from the human fraction. Although the latter contains at least five components, a large part of it consists of orosomucoid and accordingly behaves as a pre-albumin on starch-gel electrophoresis at approximately $\mathrm{pH} 9$. In contrast, the fraction from guinea-pig serum contains little or no pre-albumin; it resolves into five bands of roughly comparable magnitude and one minor band. A satisfactory comparison between the guinea-pig and human fractions cannot be made until much more is known about the properties of the proteins of guinea-pig serum.

\section{SUMMARY}

1. With a view to studies on acidic glycoproteins present in guinea-pig serum, a fraction (fraction $\mathrm{I}$ ) has been isolated from the latter by means of chromatography with carboxymethylcellulose. It represents about $15 \%$ of the protein-bound hexose of guinea-pig serum.

2. Fraction $I$ is made up almost entirely of $\alpha$ globulins. A large part of it consists of material which is formed of components which are very similar in a number of physical properties. This material resolves into a number of bands on starchgel electrophoresis at $\mathrm{pH} \mathbf{3 . 4}$ and two or three immunologically distinct components have been detected in it. The remainder of fraction $I$ is composed of perhaps as many as ten components. These minor components often possess some physical properties which are similar to those of the constituents forming the major part of fraction I. For example, most components have a relatively low isoelectric point and most are soluble in perchloric acid. A large part of fraction I sediments at a similar rate in the ultracentrifuge. An estimate has been made of the molecular weight of the material which behaves in this way, and a value for fraction I as a whole has also been obtained. Most or all of the components of fraction I are, however, immunologically distinct from one another; they show immunological identity with substances present in guinea-pig serum.

3. Little or no qualitative difference between samples of fraction $I$ isolated from the serum of a number of individual guinea pigs could be detected by electrophoresis at $\mathrm{pH} \mathbf{3 . 4}$ or immunological analysis.

4. The total carbohydrate content of fraction I is about $19 \%$; this is principally made up of galactose, mannose, hexosamine and sialic acid. Evidence has been obtained that most or all of the hexosamine is present in the form of $\mathrm{N}$-acetylglucosamine and that sialic acid occurs, perhaps largely or entirely, as an $O$-acetyl derivative of $N$. acetylneuraminic acid, possibly the 4-O-acetyl derivative. Traces of uronic acid and possibly fucose also occur.

5. A study has been made of the conditions which are required to bring about the release of various sugar residues by treatment with acid. A method which involves heating with a mixture of Dowex 50 and $0 \cdot 25 \mathrm{~N}$-hydrochloric acid has been used to bring about the liberation of all sugars other than sialic acid.

6. Under appropriate conditions, up to $80 \%$ of the sialic acid of fraction I can be released by the action of neuraminidase. This and other evidence indicates that most or all of the sialic acid residues occupy terminal positions.

7. The composition of the perchloric acidsoluble protein fraction of guinea-pig serum has been investigated with particular reference to the importance of components of fraction $I$ as con- 
stituents of the fraction. Up to six components of fraction $I$ were detected in this fraction, but together they account for only about $20 \%$ of it. The remainder of the fraction is made up of a number of other serum proteins: these are $\alpha$ - and $\beta$-globulins, at least a number of which are glycoproteins. The carbohydrate composition of the fraction is rather similar to that of fraction $I$.

This work was supported by the Medical Research Council and the U.S. Public Health Service (Research Grant AM-04346, National Institute of Arthritis and Metabolic Diseases). We wish to express our gratitude to these Bodies and also to Unilever Ltd., who gave a maintenance grant to H.S.S. We are indebted to Dr J.J. Connell for ultracentrifuge analyses, Professor G. Blix and Miss P. M. Carroll for sialic acid samples, Dr J. H. Humphrey and Dr H. J. Rogers for valuable discussions, and Dr T.S. Work for his comments on the manuscript of this paper. We thank Miss E. Bissett, Mrs M. Cowie and Mr J. C. Jamieson for technical assistance.

\section{REFERENCES}

Ada, G. L., French, E. L. \& Lind, P. E. (1961). J. gen. Microbiol. 24, 409.

Aminoff, D. (1961.) Biochem. J. 81, 384.

Anastassiadis, P. A. \& Common, R. H. (1958). Canad. J. Biochem. Physiol. 36, 413.

Biserte, G., Havez, R. \& Hayem-Levy, A. (1960). Clin. chim. Acta, 5, 272.

Bitter, T. \& Ewins, R. (1961). Biochem. J. 81, 43 P.

Blix, G. \& Lindberg, E. (1960). Acta chem. scand. 14, 1809.

Blix, G., Lindberg, E., Odin, L. \& Werner, I. (1956). Acta Soc. med. upsalien. 61, 1.

Boas, N. F. (1953). J. biol. Chem. 204, 553.

Bodman, J. (1960). In Chromatographic and Electrophoretic Techniques, vol. 2, p. 91. Ed. by Smith, I. London: William Heinemann Ltd.

Boström, H., Rodén, L. \& Yamashina, I. (1958). J. biol. Chem. 230, 381.

Bourrillon, R. \& Michon, J. (1959). Bull. Soc. Chim. biol., Paris, 41, 267.

Campbell, P. N. \& Stone, N. E. (1957). Biochem. J. 66, 19. Cardini, C. E. \& Leloir, L. F. (1957). J. biol. Chem. 225, 317.

Chan, B. G. \& Cain, J. C. (1961). Nature, Lond., 192, 69.

Cohen, S. (1957). S. Afr. J. med. Sci. 23, 245.

de Vaux St Cyr, C. (1960). Proc. 7th Colloq. Protides biol. Fluids, Bruges, p. 48. Ed. by Peeters, H. Amsterdam: Elsevier.

de Vaux St Cyr, C., Courcon, J. \& Grabar, P. (1958). Bull. Soc. Chim. biol., Paris, 40, 579.

Dische, Z. \& Shettles, L. B. (1948). J. biol. Chem. 175, 595. Dische, Z. \& Shettles, L. B. (1951). J. biol. Chem. $192,579$. Faillard, H. (1959). Hoppe-Seyl. Z. 317, 257.

Fischer, F. G. \& Nebel, H. J. (1955). Hoppe-Seyl. Z. 302, 10.

Frahn, J. L. \& Mills, J. A. (1959). Aust. J. Chem. 12, 65. Gardell, S. (1953). Acta chem. scand. 7, 207.

Gottschalk, A. (1960). In The Enzymes, 2nd ed., vol. 4, p. 461. Ed. by Boyer, P. D., Lardy, H. \& Myrbäck, K. New York: Academic Press Inc.
Haab, W. \& Anastassiadis, P. A. (1961). Canad. J. Biochem. Physiol. 39, 671.

Hestrin, S. (1949). J. biol. Chem. 180, 249.

Hunter, J. R. (1959). Nature, Lond., 183, 1283.

Kohn, J. (1958). Clin. chim. Acta, 3, 450.

Kohn, J. (1960). In Chromatographic and Electrophoretic Techniques, vol. 2, p. 56. Ed. by Smith, I. London: William Heinemann Ltd.

Kraan, J. G. \& Muir, H. (1957). Biochem. J. 66, 55 .

Kunkel, H. G. \& Tiselius, A. (1951). J. gen. Physiol. 35, 89.

Lowry, O. H., Rosebrough, N. J., Farr, A. L. \& Randall, R. J. (1951). J. biol. Chem. 193, 265.

Ludoweig, J. \& Dorfman, A. (1960). Biochim. biophys. Acta, 38, 212.

Miettinen, T. \& Takki-Luukkainen, I.-T. (1959). Acta chem. scand. 13, 856.

Miller, G. L. (1959). Analyt. Chem. 31, 964.

Montreuil, J. (1957). Bull. Soc. Chim. biol., Paris, 39, suppl. 3, 3.

Montreuil, J. \& Scheppler, N. (1959). Bull. Soc. Chim. biol., Paris, 41, 13.

Moretti, J., Boussier, G. \& Jayle, M.-F. (1958). Bull. Soc. Chim. biol., Paris, 40, 59.

Ouchterlony, O. (1953). Acta path. microbiol. scand. 32, 231.

Park, J. T. \& Johnson, M. J. (1949). J. biol. Chem. 181, 149.

Partridge, S. M. (1948). Biochem. J. 42, 238.

Partridge, S. M. (1949). Nature, Lond., 164, 443.

Peterson, E. A. \& Sober, H. A. (1956). J. Amer. chem. Soc. 78, 751.

Popenoe, E. A.\& Drew, R. M. (1957). J. biol. Chem. 228,673.

Porath, J. (1960). Biochim. biophys. Acta, 39, 193.

Poulik, M. D. (1957). Nature, Lond., 180, 1477.

Poulik, M. D. \& Smithies, O. (1958). Biochem. J. 68, 636.

Riou, G., Paoletti, C.\& Truhaut, R.(1962). Bull. Soc. Chim. biol., Paris, 44, 149.

Roseman, S. \& Daffner, I. (1956). Analyt. Chem. 28, 1743.

Schachman, H. K. (1959). Ultracentrifugation in Biochemistry, p. 181. New York: Academic Press Inc.

Schmid, K., Binette, J. P., Kamiyama, S., Pfister, V. \& Takahashi, S. (1962). Biochemistry, 1, 959.

Simkin, J. L., Skinner, E. R. \& Seshadri, H. S. (1963). Proc. 10th Colloq. Protides biol. Fluids, Bruges, p. 208. Ed. by Peeters, H. Amsterdam: Elsevier.

Smithies, O. (1955). Biochem. J. 61, 629.

Sober, H. A., Gutter, F. J., Wycoff, M. M. \& Peterson, E. A. (1956). J. Amer. chem. Soc. 78, 756.

Spiro, R. G. (1960). J. biol. Chem. 235, 2860.

Stoffyn, P. J. \& Jeanloz, R. W. (1954). Arch. Biochem. Biophys. 52, 373.

Svennerholm, E. \& Svennerholm, L. (1958). Nature, Lond., 181, 1154.

Svennerholm, L. (1956). Acta Soc. med. upsalien. 61, 75.

Svennerholm, L. (1957). Biochim. biophys. Acta, 24, 604.

Svennerholm, L. (1958). Acta chem. scand. 12, 547.

Thompson, A. R. (1951). Aust. J. sci. Res. B, 4, 180.

Trevelyan, W. E., Procter, D. P. \& Harrison, J. S. (1950). Nature, Lond., 166, 444.

Warren, L. (1960). Nature, Lond., 186, 237.

Weimer, H. E. \& Winzler, R. J. (1955). Proc. Soc. exp. Biol., N.Y., 90, 458.

Winzler, R. J. (1955). Meth. biochem. Anal. 2, 279.

Winzler, R.J. (1960). In The Plasma Proteins, vol. 1, p. 309. Ed. by Putnam, F. W. New York: Academic Press Inc.

Yemm, E. W. \& Cocking, E. C. (1955). Analyst, 80, 209. 